American Journal of Applied Sciences 6 (6): 1126-1132, 2009

ISSN 1546-9239

(C) 2009 Science Publications

\title{
The Tunnel Boring Machine Advancements in Horizontal and Up-Hill Tunnels
}

\author{
${ }^{1}$ Stefano Fuoco and ${ }^{2}$ Pierpaolo Oreste \\ ${ }^{1}$ Soil Water Structures-Engineering Services, Trento, Italy \\ ${ }^{2}$ DITAG, Politecnico di Torino, Corso Duca degli Abruzzi 24, Torino, Italy
}

\begin{abstract}
Problem statement: Nowadays high levels of experience have been acquired in the excavation of horizontal tunnels using TBM, especially as far as tunnels with small diameters (about 4 $\mathrm{m}$ wide) are concerned. Less experience has been acquired in the excavation of tunnels under difficult alignment conditions, as in the case of steeply inclined excavations (up-hill tunnels). Approach: This study presented the results of studies which compare the production data collected for tunnels excavated with TBM in "normal" conditions (horizontal tunnel), with those derived from steeply inclined excavations (up-hill tunnels). Results: From an examination of the results obtained in the studied cases a net difference appears evident in terms of productivity between horizontal and up-hill excavations. Conclusion: Such net difference between horizontal and up-hill excavation productions can be attributed to the greater burdens of times necessary for the supply of materials and personnel, the regripping operations with fall preventer systems and, in general, the greater difficulties of carrying out ordinary and extraordinary maintenance of the machines in particularly difficult altrimetric conditions.
\end{abstract}

Key words: Tunnel Boring Machine (TBM), up-hill tunnels, advancement velocity, productivity of the excavation system

\section{INTRODUCTION}

As known, the productivity of an excavation system with full section machines, called Tunnel Boring Machines (TBM), is conditioned by a series of factors that reduce, sometimes quite drastically, the potentiality of the system itself ${ }^{[1,3,7,9]}$. The majority of these factors affect the theoretically obtainable productivity of the system in a much more pronounced manner if the altimetric trend of the tunnel that has to be excavated exceeds such inclinations that it is necessary to request the use of auxiliary equipment that allows operation under safe conditions or where it is necessary to back-install a pre-casted lining that acts as a contrast element and this occurs when one proceeds in the so-called up-hill excavation ${ }^{[2]}$.

The mean speed of advancement of a TBM is remarkably lower than the net advancement speed that the machine presents during the excavation stage ${ }^{[1,3,8]}$. The first is usually measured in $\mathrm{m} /$ days and from necessity takes into consideration the stopping times of the machine due to the installation of the supports, maintenance, the change of tools, the change of shifts and the waiting times associated to the transport system of the mucked material.
In short, the factors that can influence the productivity of an excavation system can be grouped into the following three groups ${ }^{[4,5]}$ :

- TBM characteristics and its back-up system

- Problems connected to the characteristics of the rock mass which has to be excavated

- Problems connected to the site organization

The drops in productivity due to the re-gripping that is necessary with the advancement of the machines and the back-up can be included within the group inherent to the TBM characteristics and its back-up system, as can those due to the normal and extraordinary maintenance of the system and those due to an inadequate "power" of the excavation machine for the mechanical strength parameters of the rock mass. For each type of rock there is in fact a critical thrust force on the tool and an optimal force connected to the lowest waste of specific energy (Fig. 1), the thrust force should fall between these two values otherwise the head will work in anomalous conditions that could cause damage to the tools and slow down the advancement. In the group relative to the problems arising from the geological and geomechanical structure, the problems connected to the installation of a support system of the

Corresponding Author: Pierpaolo Oreste, Department of Land, Environment and Geotechnology Engineering (DITAG), Politecnico di Torino, Corso Duca Degli Abruzzi 24, 10129, Torino, Italy Tel: +39.11 .0907608$ 


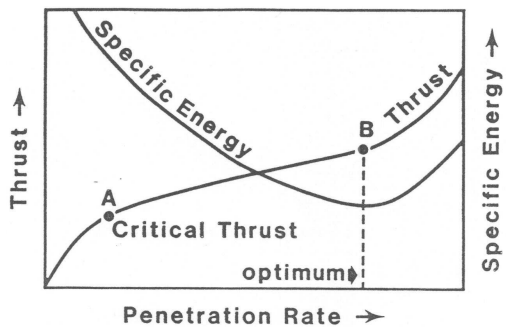

Fig. 1: Ratio between the thrust force at the head or the specific excavation energy and the net velocity of advancement of the TBM

tunnel can be considered as can those relative to the exchange of the cutters caused by the wear or support breakage, to the local alteration and fracturing degree of the rock mass and to the existing hydro-geological structure $^{[5-7]}$. Finally the problems deriving from the adopted mucking system, the shift changes of the workers and of the impositions of a contractual nature, as for example, the carrying out of investigations at the face during advancement, can all be included in the group relative to the lowering of productivity connected to the site organization.

The set of these factors, some of which are inevitable in that they are intrinsically necessary to the TBM advancement, can reduce the time potentially dedicated to excavation to a great extent and therefore also the efficiency of the system ${ }^{[4]}$.

This study illustrates the results of a comparative analysis between the productions of tunnels excavated with TBMs with sub-horizontal axis and those obtained in the case of up-hill tunnels. The purpose of this comparison is that of supplying indications on the real productivity of the excavation system using TBMs for altimetric situations similar to those that have been examined.

\section{MATERIALS AND METHODS}

In "normal" altimetric conditions the cycle that characterizes the mechanized excavation with TBMs basically consists of two stages: the real excavation, which is possible up to the end of the jack length and the recall of the machine head support elements and of the back-up (re-gripping) during which the excavation operations are interrupted. An exception to this is represented by the double shield machines for which, if the installation of supports behind the machine is associated to the excavation operation, the excavation phase can occur continuously without the re-gripping operations influencing the production to any great extent.

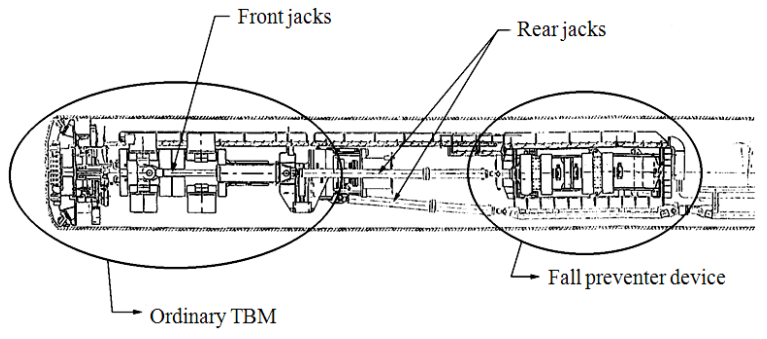

Fig. 2: Typical configuration of open TBMs equipped for up-hill excavation

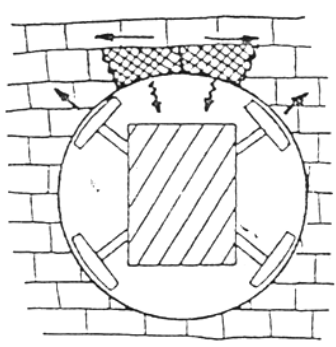

$\{$ Fractures in the roof

By tensile stresses

From the gripper pads

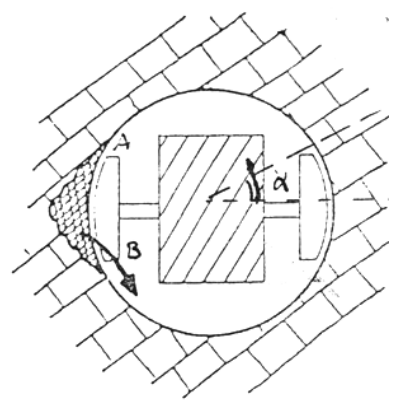

Zone of crushed rock

Under the gripper pads
Fig. 3: Problems relative to the application of remarkable contrast forces on the tunnel wall, by the fall preventer gripper device

When up-hill excavating, in the case of open TBMs, it is necessary to equip the excavation system with means that allows re-gripping of the machines in safe conditions. This can be obtained by arranging a double system of grippers. The added grippers, which make up the "fall preventer device" (Fig. 2), support the entire weight of the machine and allow the excavation to be performed in safe conditions. Their action allow the TBM grippers to act as exclusive contrast for the advancement, as happens for TBMs in excavation operations with horizontal altimetric axis (Fig. 2).

A remarkable force should be applied overall from the grippers of the fall preventer device on the tunnel walls to contrast the weight of the machine. In some cases, when the rock mass appears fractured with low persistence discontinuities, problems can occur due to the detachment of rock blocks from the walls (Fig. 3).

Another significant difference from the horizontal excavation system is constituted by the movement of personnel and supply materials. In up-hill excavation the system is endowed with winches and cable hauling bogies which are much slower than the vehicles used in horizontal excavation. On the other hand, the mucking can occur more quickly as it is possible to arrange the site for the gravity dumping of the excavated materials in the case of up-hill excavation. 


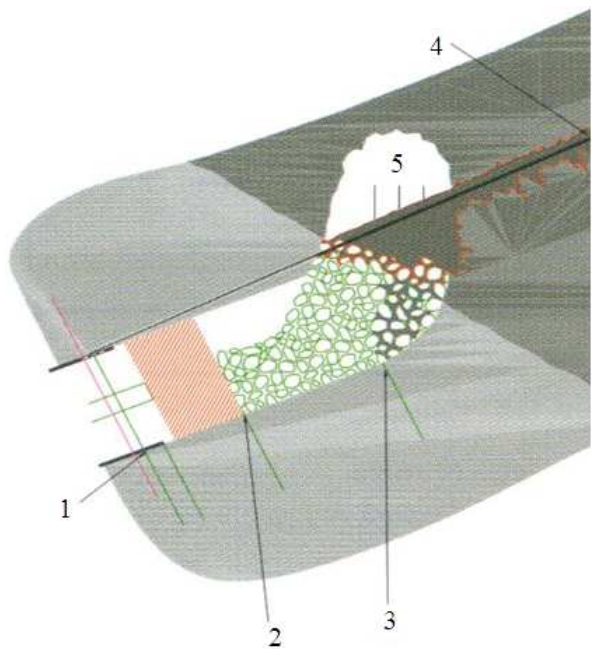

Fig. 4: An example of collapse of poor geomechanical quality material ahead of the TBM head: Difficult condition for re-establishing stability in the area through remedial works. Key: (1): Support panels; (2): Cutterhead position during execution of remedial works; (3): Cutterhead position during the roof instability; (4): Execution of grouted steel bars in the roof area; (5): Instability area ${ }^{[1]}$

When a collapse occurs, due to the presence of an unforeseen fault of material of poor geotechnical characteristics, which involves the area close to the excavation face, the lateral grippers are also given the task of supporting the weight of the portion of collapsed rock and the operations of re-establishing stability in the area are more difficult and longer (Fig. 4) ${ }^{[2]}$.

\section{RESULTS}

The available data relative to production obtained in the excavation with TBMs of tunnels with diameters between 3.2 and $4.7 \mathrm{~m}$, with sub-horizontal and up-hill axis, are here given.

Data relative to up-hill excavations: The main characteristics of the examined cases are shown in Table 1. It can be seen how the open machines have mainly worked inside massive formations while shielded or double shielded machines were used for relatively worse formations. From the qualitative point of view, with reference to the Bieniaski RMR classification, according to SIA regulations or O-Norm 2203 , which was the reference classifications used in the cited cases, it can be indicated that the formations crossed by the open TBMs could be classified as good

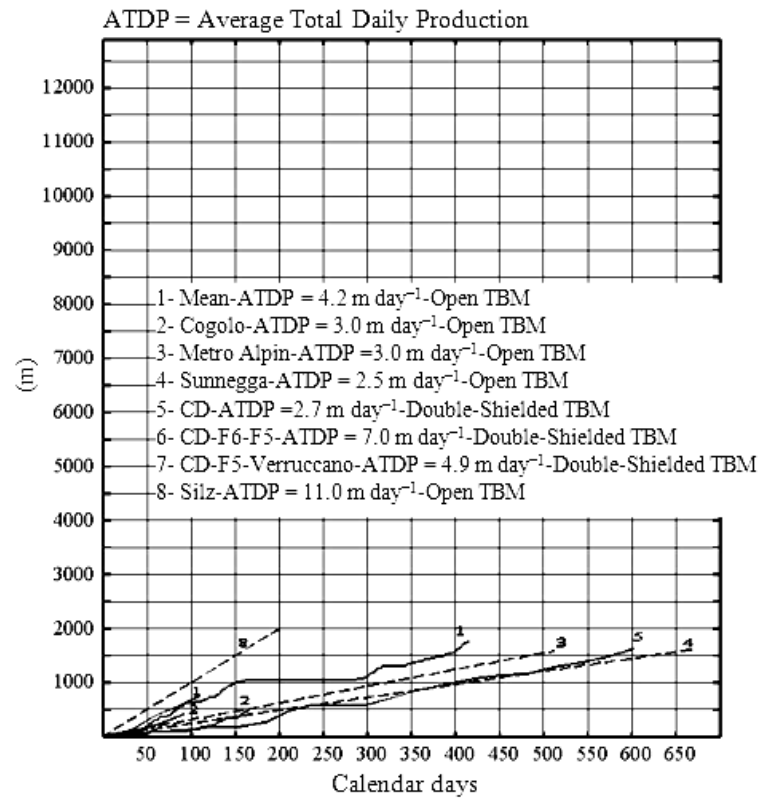

Fig. 5: Total productions obtained in the up-hill excavations

or very good quality masses (RMR Class I or II and equivalents) for percentages between 70 and $90 \%$, with uniaxial compression strength of the rock matrixes that vary from a minimum of $50 \mathrm{MPa}$ for the fine schists to a maximum of $300 \mathrm{MPa}$ for the amphiboles. The mean of the later falls between 100 and $120 \mathrm{MPa}$. In the case of shielded TBMs, no classes of greater reference are available; the uniaxial compression strength of the matrixes involved in the excavation fall around $25 \mathrm{MPa}$. The mean production expressed in metres of excavation, referring to daytime production (therefore including all the factors that have constrained the values) are shown in Table 2. The trend of advancement obtained for the examined cases are shown in Fig. 5, when available.

From an examination of the Table 2 it can be noticed how there are significantly different efficiencies, while, with the exception of two cases, the mean global production falls around values between 2.5 and $4.9 \mathrm{~m} \mathrm{day}^{-1}$. It is also possible to notice that the difference between the mean daily productions and the maximum ones are higher for the open machines than for the shielded ones.

This aspect should be compared with the influence that the characteristics of the rock mass have on the open machines and on the shielded ones; these last allow productions that are less influenced by the geomechanical characteristics of the rock mass. It should be underlined that in the case of Clauson Dixence, the rock mass appears on average of a lower quality than the mass excavated with open TBMs. 
Am. J. Applied Sci., 6 (6): 1126-1132, 2009

Table 1: Characteristics of the analysed up-hill tunnels

\begin{tabular}{|c|c|c|c|c|c|}
\hline Project & $\mathrm{L}(\mathrm{m})$ & $\mathrm{P}(\%)$ & TBM Model & $\mathrm{D}(\mathrm{m})$ & Prevalent rock mass \\
\hline Maen & 1750 & $24-35$ & Open & 4.2 & $\begin{array}{l}\text { Calceschists; Meta-gabbros; Meta-basites; } \\
\text { Serpentinites; Schists }\end{array}$ \\
\hline Cogolo & 500 & 42 & Open & 3.9 & $\begin{array}{l}\text { Paragneiss; M.pegmatites; Schists; Anphibolites } \\
\text { (presence) }\end{array}$ \\
\hline Metro Alpine & 1580 & $17-48$ & Open & 4.2 & $\begin{array}{l}\text { Serpentinites; Anphibolites; Prasinites e } \\
\text { Chloritoschists }\end{array}$ \\
\hline Zermatt Sunnegga & 1700 & $36-63$ & Open & 3.7 & $\begin{array}{l}\text { Anphibolites; Prasinites; Chloritoschists; } \\
\text { Calceschists }\end{array}$ \\
\hline Clauson Dixence Section F8/F6 & 1600 & 68 & Double shielded & 4.7 & $\begin{array}{l}\text { Alternance of schists, sandstones and } \\
\text { carboniferous slates; Dolomitic limestones }\end{array}$ \\
\hline Clauson Dixence Section F6/F5 & 700 & $15-64$ & Double shielded & 4.7 & $\begin{array}{l}\text { Alternance of schists, sandstones and } \\
\text { carboniferous slates; Anidrites }\end{array}$ \\
\hline $\begin{array}{l}\text { Clauson Dixence Section } \\
\text { F5/Verruccano }\end{array}$ & 450 & 68 & Shielded & 4.4 & $\begin{array}{l}\text { Alternance of quartzites and limestones; } \\
\text { carboniferous schists }\end{array}$ \\
\hline Silz & 1995 & 80 & Open & 3.2 & Schists, gneiss; mica-schists \\
\hline
\end{tabular}

Key: L: Tunnel length (approximate); P: Inclination; D: Tunnel diameter

Table 2: Productions obtained for up-hill excavations

\begin{tabular}{llllll}
\hline Project & TBM model & D $(\mathrm{m})$ & AGDP $\left(\mathrm{m} \mathrm{g}^{-1}\right)$ & $\mathrm{MDP}_{\left(\mathrm{m} \mathrm{g}^{-1}\right)}$ & Efficiency $(\%)$ \\
\hline Maen & Open & 4.2 & 4.2 & 30.0 & 16 \\
Cogolo & Open & 3.9 & 3.0 & 24.0 & 11 \\
Metro Alpine & Open & 4.2 & 3.1 & 19.6 & 33 \\
Zermatt Sunnegga & Open & 3.7 & 2.5 & 18.3 & 50 \\
Clauson Dixence Section F8/F6 & Double shielded & 4.7 & 2.7 & 14.4 & 7 \\
Clauson Dixence Section F6/F5 & Double shielded & 4.7 & 7.0 & 17.2 & 16 \\
Clauson Dixence Section F5/Verruccano & Shielded & 4.4 & 4.9 & 12.3 & 23 \\
Silz & Open & 3.2 & 11.0 & - & $30 \div 39(*)$ \\
\hline
\end{tabular}

Key: D: Tunnel diameter; AGDP: Average global daily production; MDP: Maximum daily production; Efficiency: Ratio between real time spent on the excavation and the potential excavation time; $(*)$ as a function of the rock mass type.

Table 3: Main characteristics of the analysed horizontal excavations

\begin{tabular}{|c|c|c|c|c|c|}
\hline \multicolumn{2}{|l|}{ Project } & $\mathrm{L}(\mathrm{m})$ & $\mathrm{D}(\mathrm{m})$ & Prevalent rock mass & Case $\mathrm{No}^{\circ}$ \\
\hline \multicolumn{2}{|l|}{$\begin{array}{l}\text { Evinos-Mornos } \\
(0-8090 \mathrm{~m})\end{array}$} & 8090 & 4.2 & $\begin{array}{l}\text { Triassic limestone, Flysh } \\
\text { (sandstone and siltstone) }\end{array}$ & 1 \\
\hline \multicolumn{2}{|l|}{$\begin{array}{l}\text { Evinos-Mornos } \\
(25262-29392 \mathrm{~m})\end{array}$} & 4130 & 4.2 & Flysh (sandstone and siltstone) & 2 \\
\hline \multicolumn{2}{|l|}{ Alassio } & 2310 & 3.6 & Clayed and limed mudstone & 3 \\
\hline \multicolumn{2}{|l|}{ Cardano } & 3070 & 3.9 & Ignimbrite reolitic & 4 \\
\hline \multicolumn{2}{|l|}{ Val D'arzino } & 5660 & 4.5 & Siltstone and mudstone & 5 \\
\hline \multicolumn{2}{|l|}{ Bleu Montain } & 5940 & 3.4 & Sandstone & 6 \\
\hline \multicolumn{2}{|l|}{ Prato Isarco } & 12500 & 3.5 & Ignimbrite, Tuff, fillades & 7 \\
\hline \multirow{3}{*}{$\begin{array}{l}\text { Pre Saint Didier } \\
\text { Avise }\end{array}$} & Left Tube & 2145 & 3.9 & $\begin{array}{l}\text { Calceschists and schists arenaceous, } \\
\text { black schists, sandstones }\end{array}$ & 8 \\
\hline & Left Tube & 1285 & 4.5 & Fine gneiss and micaschists & 9 \\
\hline & Right Tube & 2640 & 4.5 & & 10 \\
\hline \multirow[t]{2}{*}{ Leverogne } & Left Tube & 1630 & 3.9 & Calceschists, Fine gneiss and & 11 \\
\hline & Right Tube & 1650 & 3.9 & Micaschists & 12 \\
\hline \multirow[t]{2}{*}{ Arvier } & Left Tube & 2360 & 3.9 & Fine gneiss and Micaschists & 13 \\
\hline & Right Tube & 2355 & 3.9 & & 14 \\
\hline \multirow[t]{3}{*}{ Villeneuve } & Left Tube & 2750 & 3.9 & Formation of calceschists and green & 15 \\
\hline & Right Tube & 570 & 4.7 & rocks (ophicalcites) & 16 \\
\hline & Right Tube & 2200 & 3.9 & & 17 \\
\hline
\end{tabular}

Key: L: Length of tunnel (approximate); D: Tunnel diameter

The inclination of the tunnel also appears to play a certain role in the reduction of the net speed of advancement.

Data relative to horizontal excavations: The main characteristics of the examined cases are shown in Table 3 . These are only limited to tunnel excavation with open TBMs and slopes for which it has not proved necessary to make use of machines equipped with fall preventer systems.

Qualitatively speaking, with reference to the previously mentioned classifications, it can be stated that the formations crossed by the open TBMs can be classified, with the exception of case 2, as masses of 
discrete-good quality (Classes II or III according to the Bieniawski or equivalent classifications) for overall length percentages of between 60 and $70 \%$, with uniaxial compression strength of the rock matrixes that vary between a minimum of 20-30 $\mathrm{MPa}$ for fine sedimentary rocks to a maximum of $120-130 \mathrm{MPa}$ for metamorphic rocks.

The mean productions expressed in excavation metres per day, referring to daytime production, are shown in Table 4. The trend of the advancement obtained in the examined cases is shown in Fig. 6a, when available.

The data shown in the table bring to light the extreme variability of the global production. From a first examination of the causes of this variability, a close connection has been deduced between the characteristics of the excavated rock mass and in particular for the geomechanical quality of the rock mass and with the presence of poor rock, from the geomechanical point of view, or of peculiar areas such as, for example, those with the presence of gas.

The quality of the rock mass, which conditions the installation of support systems and therefore the consequent stopping times, reduces the productivity of the system in a proportional manner, while the presence of particular areas can lower the global production because of stopping times that are necessary to resolve the problem. It should be underlined that in the examined cases the stops of this kind were always of a modest number (usually one single episode, rarely two). As far as the production is concerned, it has been ascertained that the highest ones correspond to good-very good quality rock masses found in an almost uniform manner along the tract, while the lowest production corresponds to mediocre rock masses associated with one or two stopping episodes to resolve precise cases.

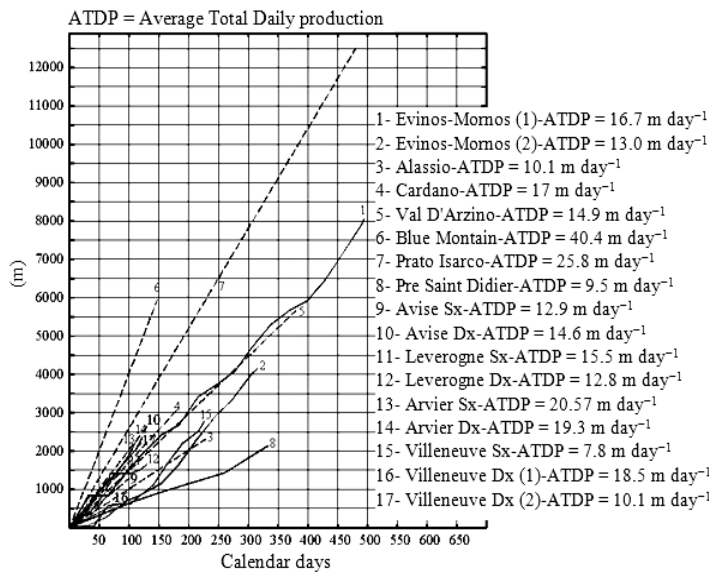

(a)

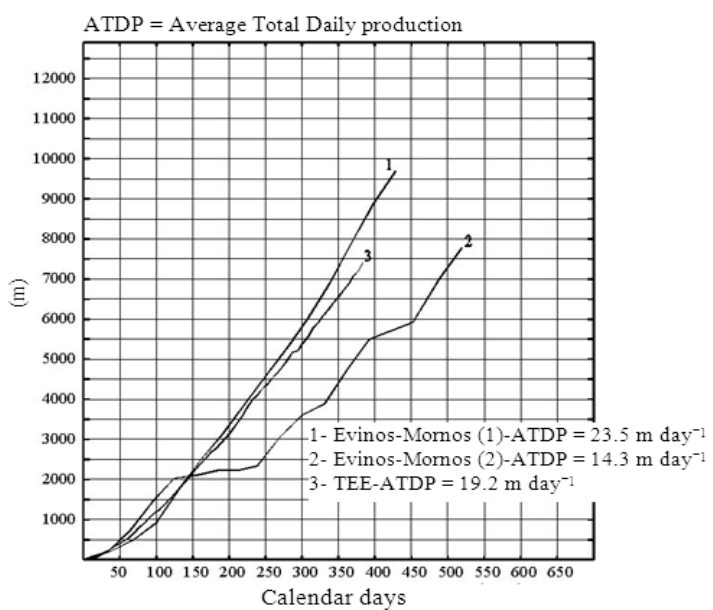

(b)

Fig. 6: Total production obtained in the horizontal excavations with open TBMs (a) and double shielded TBMs (b)

Table 4: Productions obtained for horizontal excavations

\begin{tabular}{|c|c|c|c|c|c|c|}
\hline Project & & $\mathrm{L}(\mathrm{m})$ & $\mathrm{D}(\mathrm{m})$ & $\operatorname{AGDP}\left(\mathrm{m} \mathrm{g}^{-1}\right)$ & $\operatorname{MDP}\left(\mathrm{m} \mathrm{g}^{-1}\right)$ & Efficiency (\%) \\
\hline Evinos-Mornos (da 0 a $8090 \mathrm{~m}$ ) & & 8090 & 4.2 & 16.30 & 53 & 28 \\
\hline Evinos-Mornos (da 25262 a 29392 m) & & 4130 & 4.2 & 13.20 & 42 & 19 \\
\hline Alassio & & 2310 & 3.6 & 11.70 & 53 & 24 \\
\hline Cardano & & 3070 & 3.9 & 17.00 & 51 & 43 \\
\hline Val D'arzino & & 5660 & 4.5 & 15.00 & 90 & 26 \\
\hline Bleu Montain & & 5940 & 3.4 & 40.40 & 173 & - \\
\hline Prato Isarco & & 12500 & 3.5 & 25.80 & 78 & - \\
\hline Pre Saint Didier & Left Tube & 2145 & 3.9 & 9.50 & 59 & $30-40$ \\
\hline \multirow[t]{2}{*}{ Avise } & Left Tube & 1285 & 4.5 & 14.60 & 47 & 34 \\
\hline & Right Tube & 2640 & 4.5 & 12.90 & 66 & - \\
\hline \multirow{2}{*}{ Leverogne } & Left Tube & 1630 & 3.9 & 13.20 & 62 & $50-60$ \\
\hline & Right Tube & 1650 & 3.9 & 15.70 & 55 & 60 \\
\hline \multirow[t]{2}{*}{ Arvier } & Left Tube & 2360 & 3.9 & 19.10 & 40 & 58 \\
\hline & Right Tube & 2355 & 3.9 & 20.40 & 49 & 61 \\
\hline \multirow[t]{3}{*}{ Villeneuve } & Left Tube & 2750 & 3.9 & 7.80 & 17 & $30-40$ \\
\hline & Right Tube & 570 & 4.7 & 18.50 & 53 & $40-50$ \\
\hline & Right Tube & 2200 & 3.9 & 12.20 & 59 & 32 \\
\hline
\end{tabular}

Key: D: Diameter; L: Length; AGDP: Average global daily production; MDP: Maximum daily production; Efficiency: Ratio between the real time spent for excavation and potential excavation time 
Am. J. Applied Sci., 6 (6): 1126-1132, 2009

Table 5: Main characteristics and productions for three excavation cases using double shielded TBMs

\begin{tabular}{lllllll}
\hline Project & $\mathrm{L}(\mathrm{m})$ & $\mathrm{D}(\mathrm{m})$ & Prevalent rock masses & AGDP $\left(\mathrm{m} \mathrm{g}^{-1}\right)$ & $\mathrm{MDP}\left(\mathrm{m} \mathrm{g}^{-1}\right)$ & Efficiency $(\%)$ \\
\hline Evinos-Mornos $(8090-17790 \mathrm{~m})$ & 9700 & 4.0 & Flysh (sandstone and siltstone) & 22.7 & 60.0 & $40(*)$ \\
Evinos-Mornos (17790-25260 m) & 7310 & 4.0 & $\begin{array}{l}\text { Flysh (sandstone and siltstone), } \\
\text { Triassic limestone }\end{array}$ & 13.8 & 50.0 & $40(*)$ \\
Tolo Effluent Export (T.E.E.) & 7470 & 3.6 & Granite & 19.2 & 43.0 & $35(*)$ \\
\hline
\end{tabular}

Key: (*): For rock mass classes (Bieniawski classification) from I to III

It could be interesting to compare these productions with those obtained in three cases of horizontal excavation carried out using double shielded TBMs, with installation of precasted linings, with comparable diameters. The characteristic data of these 3 cases and the obtained productions are shown in Table 5, while the advancement trend is shown in Fig. $6 \mathrm{~b}$.

It should be considered that the Evinos-Mornos project the excavation was performed inside rock masses prevalently between the class III and IV and mean uniaxial compression strength of the intact rock between 60 and $80 \mathrm{MPa}$, while the T.E.E. project was obtained excavating a tunnel inside a rock mass of prevalently class II and III, with mean uniaxial compression strength of the order of $150 \mathrm{MPa}$.

\section{CONCLUSION}

From an examination of the results obtained in the studied cases a net difference appears evident in terms of productivity between horizontal and up-hill excavations. The production fields of variability registered in the examined cases are shown in Fig. 7. AS foreseen, in the horizontal excavations the variability in the global production is extremely high. In the examined cases it varies between 7.8 and $40.4 \mathrm{~m} \mathrm{day}^{-1}$ and is closely connected to the average geomechanical quality of the rock mass. Only in some cases did the resolving of an incident (that is, concentrated stopping time) lead to an important reduction of the mean global production. In general, the higher limit of this field of variability is correlated to good-optimal quality rock masses; on the other hand, the values close to the lower limit are correlated to rock masses of mediocre quality. Inside this field of variability, the production obtained with double shielded TBMs, supported by the installation of precasted linings, can be found, (at least for the three examined cases) in an intermediate position with global production between 13.8 and $22.7 \mathrm{~m} \mathrm{day}^{-1}$. This allows one to confirm what has already been indicated by various authors in merit of a lower susceptibility of the advancement of this kind of TBM to the quality of the rock mass involved in the excavation. It should be considered that with the placing of the precast lining

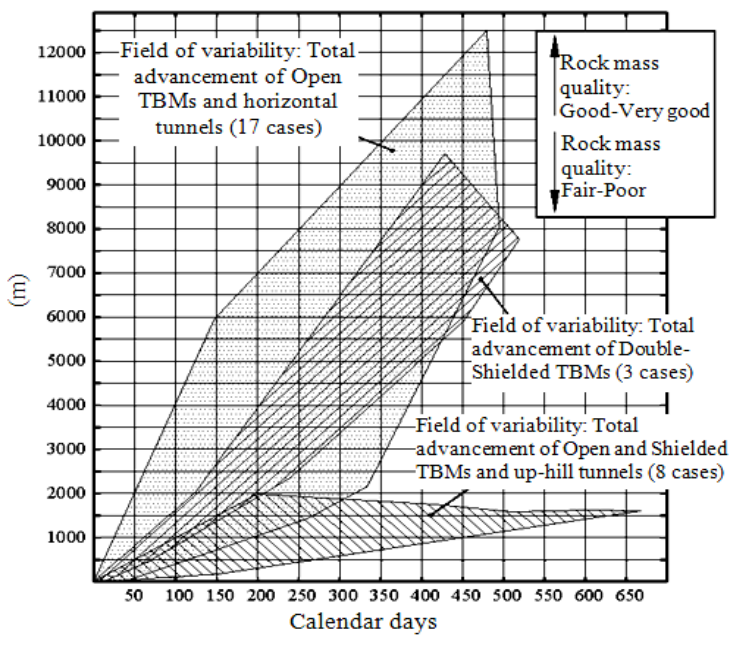

Fig. 7: Variability fields of the horizontal and up-hill excavations

behind the machine, the shielded TBM can supply a final lining and therefore, strictly speaking, a comparison with open TBMs should be performed also considering, in the global production, the installation of any final supports.

The analysed cases of up-hill excavation highlight a lower variability of the mean global production. The field of production is limited on the upper side by a mean production equal to $11 \mathrm{~m} \mathrm{day}^{-1}$ and on the lower side by a mean production equal to $2.5 \mathrm{~m} \mathrm{day}^{-1}$.

Inside this field of variability it is not possible to distinguish the benefit of the double shielded TBM on the excavation if not of the implicit benefit in the case of use of precasted linings.

Such net difference between horizontal and up-hill excavation productions can be attributed to the greater burdens of times necessary for the supply of materials and personnel, the regripping operations with fall preventer systems and, in general, the greater difficulties of carrying out ordinary and extraordinary maintenance of the machines in particularly difficult altrimetric conditions. Any incidents, furthermore, require longer times to resolve, therefore contributing to a further diminishing of the mean advancement velocity. 


\section{REFERENCES}

1. Barton, N., 2000. TBM Tunneling in Jointed and Faulted Rock. 1st Edn., Taylor and Francis, Balkema, Rotterdam, ISBN: 9058093417, pp: 184.

2. Bethaz, E., S. Fuoco, S. Mariani, P. Porcari and E. Rosazza Bondibene, 2000. The up-hill excavation using TBM: The experience of Maen tunnel. Gallerie e Grandi Opere Sotterranee. N.61, Agosto 2000.

3. Dolcini, G., S. Fuoco and R. Ribacchi, 1996. Performance of TBMs in complex rock masses. Proceeding of the International North American Tunneling, (INAT'96), Balkema, Rotterdam, pp: $145-154$.

4. Gaye, F., 1972. Efficient excavation. Tunnels Tunnel., $\quad 4$ : 39-48, 135-143. http://md1.csa.com/partners/viewrecord.php?reque ster $=$ gs\&collection $=$ ENV \& recid $=7213746 \& q=$ Effi cient+excavation. \&uid $=1168860 \&$ setcookie $=y e s$

5. Gehring, K., 1997. Classification of drillability, cuttability, borability and abrasivity in Tunneling. Felsbau, 15: 183-191.
6. Grandori, R., 1996. The universal TBM in the year 2000. Technical aspects and contractor considerations. Gallerie e grandi opere in sotterraneo-November 1996 N.50.

7. Innaurato, N., C. Oggeri and P.P. Oreste, 2001. Performance and modeling of indenters and cutting tools for the assessment of the borability in rock tunneling. Proceeding of the Eurock Symposium Rock Mechanics, a Challenge for Society, pp: 573-578.

8. Klein, S., M. Schmoll and T. Avrey, 1995. TBM performance at four hard rock tunnels in California. Proceeding of the Rapid Excavation and Tunneling Conference, SEM, Jan. 1-1, San Francisco, $\quad$ pp: 15-15. http://www.onemine.org/search/summary.cfm/TB M-Performance-At-Four-Hard-Rock-Tunnels-InCalifornia?d=DA8AB8E0075ABD67DFFEF353E EE98E5D689C74CBA7FBF9745209E2E999863B C837278

9. Nishimatsu, Y., 1972. The mechanics of rock cutting. Int. J. Rock Mech. Min. Sci. Geomech. Abst., 9: 261-270. 